\title{
PEDAGOGICAL CONTENT KNOWLEDGE MAHASISWA PENDIDIKAN FISIKA UNIVERSITAS JAMBI PADA PRAKTIK LAPANGAN PERSEKOLAHAN
}

\author{
M.Hidayat ${ }^{1}$, Rahma Dani ${ }^{2}$, Neneng Lestari ${ }^{3}$ \\ 1,2,3 Prodi Pendidikan Fisika UniversitasJambi, Jambi, Indonesia \\ Corresponding author email: m.hidayat@unja.ac.id
}

\section{Info Artikel}

Diterima:

03 Juni 2020

Disetujui:

16 Juni 2020

Dipublikasikan:

30 Juni 2020

\begin{abstract}
Abstrak:
Penelitian ini bertujuan untuk mendeskripsikan kemampuan pedagogical content knowledge mahasiswa Pendidikan Fisika Universitas Jambi yang mengikuti Praktik Lapangan Persekolahan (PLP). Jenis penelitian ini yaitu penelitian survey. Populasi penelitian ini mahasiswa yang sedang mengikuti PLP sebanyak 85 orang. Jumlah sampel yang digunakan $20 \%$ dari populasi. Data dikumpulkan menggunakan kuisioner. Data dianalisis secara deskriptif. Hasil penelitian menunjukkan bahwa kemampuan Pedagogical Content Knowledge mahasiswa berada pada kategori baik. Aspek pedagogical content knowledge terdiri dari subject matter knowledge, instruction representation and strategies, instructional objective and context dan knowledge of student understanding.
\end{abstract}

Kata kunci: Pedagogi, konten, pengetahuan.

\begin{abstract}
:
This study aims to describe the ability of pedagogical content knowledge students of Physics Education Jambi University who take School Field Practices (SFP). This research was a survey research. The population of this research was 85 students who are taking SFP. The number of samples used was $20 \%$ of the population. Data were collected using a questionnaire. Data were analyzed descriptively. The results showed that the students' pedagogical content knowledge ability was in a good category. Aspects of pedagogical content knowledge consist of subject matter knowledge, instruction representation and strategies, instructional objective and context and knowledge of student understanding.
\end{abstract}

Keywords: Pedagogy, content, knowledge. 


\section{Pendahuluan}

Pendidikan yang berkualitas sangat ditentukan oleh kualitas seorang guru. Guru merupakan ujung tombak yang menentukan keberhasilan dalam pembelajaran, karena guru yang akan berhubungan langsung dengan siswa. Menurut Anwar dkk (2014) guru adalah sesuatu profesi, sesuatu jabatan yang membutuhkan keahlian khusus sebagai guru. Guna menjadi seorang guru professional dituntut menguasai minimal 4 kompetensi; kompetensi pedagogis, kompetensi profesional, kompetensi sosial serta kompetensi kepribadian.

Kombinasi antara kompetensi pedagogis dan kompetensi profesional (content knowledge) yang disebut oleh Shulman (1986) sebagai kemampuan Pedagogical Content Knowledge (PCK). PCK adalah kemampuan guru dalam mengolah materi-materi pelajaran menjadi suatu pengalaman belajar siswa sehingga pemahaman siswa meningkat. Pedagogical Content Knowledge (PCK) adalah cara memberi penjelasan serta merumuskan materi pelajaran sehingga memudahkan siswa memahami materi pelajaran tersebut.

Menurut Cochran, 1993 dalam (Resbiantoro, 2013) PCK adalah merupakan cara yang dipakai guru guna membuat hubungan antara materi pelajaran dengan pengetahuan tata cara mengajar serta alasannya memadukan pengetahuan-pengetahuan tersebut dalam suatu rangkaian proses belajar mengajar. Dalam artian laian, PCK adalah kemampuan seorang guru dalam mentransfer pengetahuan ke siswa. Abell (2008) menjelaskan bahwa guru yang tingkat PCK nya tinggi, dapat diprediksi tingkat prestasi siswa yang diajar juga tinggi.

Sementara itu menurut Laoli dan Bunawan (2017) menyebutkan bahwa PCK adalah sesuatu pengetahuan yang khusus atau unik dimiliki seorang guru yang berhubungan dengan materi apa yang diajarkan, yaitu bagaimana seorang guru mengaitkan pengetahuan pedagogi dengan pengetahuannya tentang materi pelajaran. Selanjutnya NRC (1996) dalam Hariyanti (2016) menyatakan PCK merupakan pengetahuan-pengetahuan lain diluar pengetahuan tentang materi pelajaran atau konten seperti pengetahuan tentang karakteristik siswa, strategi belajar mengajar, media dan mengintegrasikannya dengan pengetahuan konten dari suatu kurikulum ke dalam suatu proses belajar mengajar yang mudah dipahami siswa. Abbit (2011) selanjutnya mengatakan PCK merupakan penggabungan daripada pengetahuan pedagogi, perencanaan dan praktik pembelajaran, dan pemilihan metode yang sesuai guna mengajarkan suatu materi pelajaran.

Anwar (2014) menguraikan tujuh komponen kemampuan Pedagogical Content Knowledge (PCK) yaitu (1) Pengetahuann tentang siswa, (2) Penguasaan standart kurikulum, (3) penguasaan terhadap proses belajar mengajar, (4) pengetahuan mengenai tata cara evaluasi, (5) pengetahuan akan sumber-sumber belajar mengajar, (6) pengetahuan tentang materi pelajaran dan (7) pengetahuan tujuan pembelajaran.

Lebih lanjut Margiyono dan Mampow (2011) mencoba mnguraikan indikator-indikator dari ketujuh komponen tersebut. Indikator dari pengetahuan tentang siswa meliputi pengetahuan dasar atau karakteristik siswa, kesulitan-kesulitan belajar siswa, konsepsi siswa, serta peningkatan kemampuan siswa. Indikator dari komponen pengetahuan tentang penguasaan standart kurikulum adalah landasan pendidikan dan penguasan kurikulum. Komponen dari penguasaan proses belajar mengajar yaitu metode-metode mengajar, memotivasi siswa, perancangan pembelajaran dan pelaksanaan belajar mengajar. Komponen evaluasi adalah aspek-aspek yang berhubungan dengan penilaian. Indikator dari sumber mengajar adalah media multimedia, fasilitas-fasilitas sekolah dan materi pelajaran. Komponen pengetahuan konten indikatornya pembuatan peta konsep, materi-materi yang sulit dan urutan-urutan materi. Komponen dari pengetahuan tujuan pembelajaran memiliki indikator tujuan umum dan tujuan khusus pembelajaran serta dan aplikasi atau orientasinya.

Sukadi dkk (2015) kemudian mengkategorikan komponen Pedagogical Content Knowledge (PCK) ke dalam Pedagogical Knowledge dan Content Knowledge (kemampuan profesional). Pedagogical Knowledge meliputi penguasaan standar kurikulum, pengetahuan pemahaman terhadap siswa, pengetahuan tentang proses pembelajaran, pengetahuan tentang evaluasi dan pengetahuan tentang penguasaan sumber daya. Sementara itu yang dimaksud dengan kompetensi pedagogik guru menurut PP No. 74 tahun 2008 pasal 3 ayat 4 (Peraturan Pemerintah RI No.74 Tahun 2008 tentang guru) adalah merupakan kemampuan guru dalam pengelolan pembelajaran peserta didik yang 
sekurangkurangnya meliputi : a.Pemahamann wawasan atau landasan kependidikaan. b.Pemahamaan terhadap peserta-didik. c.Pengembanggan kurikulum atau silabusd. Perancangan pemblajaran e.Pelaksanaan pemblajaran yg mendidik dan dialogis.f.Pemanfaatan teknology pembelajaran.g.Evaluasi terhadap hasil belajar, h.Pengembangann peserta didik untuk mengaktualisasiikan sebagai potensi yang dimiliki.

Kemampuan Content Konwledge menurut Shulman dalam Kastutik dan Hariyatmi (2017) adalah pengetahuan konsep, teori-teori, gagasan-gagasan, kerangka kerja, pengetahuan tentang pembuktiann, serta praktek-praktek dan pendekatan guna mengembangkan pengetahuan tersebut. Kemampuan Content Knowledge yang juga merupakan kompetensi profesional menurut dalam PP No 74 tahun 2008 pasal 3 ayat 7 (Peraturan Pemerintah RI No.74 Tahun 2008 tentang guru) menjelaskan yang dimaksud dg kompetensi professional adalah merupakan kemapuan guru menguasai pengetahuan bidang ilmu pengetahuan, teknologi, dan/atau seni dan budaya yang diampuya yang sekurangkurangnya meliputti penguasaan:

a. Materi pelajaran yang secara luas serta mendalam sesuai dg standar isi program satuan pendidikan, matapelajaran, dan/atau kelompok matapelajaran yang akan diampunya; dan

b. Konsep dan metoda disiplin keilmuan, teknology, atau seni yang relevan yang secara konseptionall menaungi atau koheren dg program satuan pendidikn, matapelajaran, dan/atau kelompok matapelajaran yang diampu.

Magnusson dkk dalam Purwaningsih (2015) menjelaskan Kemampuan Pedagogical Content Knowledge memiliki lima komponen utama yaitu komponen tentang orientasi terhadap pembelajarn sains, penguasaan kurikulum, pengetahuan tentang pemahaman terhadap peserta didik terhadap sains, pengetahuan bidang penilaian, dan pengetahuan tentang strategi-strategi pembelajaran. Komponen orientasi terhadap pembelajaran sains, mengacu pada pengetahuan guru untuk mencapai tujuan pembelajaran. Orientasi merupakan intruksi dan proses untuk mengatur kurikulum, dan evaluasi pembelajaran siswa. Penguasaan tentang kurikulum, memiliki dua kategori yaitu pengetahuan tujuan kurikulum serta sasaran kurikulum yang mencakup pengetahuan guru mengenai tujuan dan sasaran bagi siswa dalam mata pelajaran yang guru ajarkan, serta pengetahuan tentang program spesifik kurikulum yang terdiri dari pengetahuan tentang program dan materi yang relevan dalam pembelajaran. Pengetahuan sehubungan dengan pengalaman peserta didik akan materi sains, yaitu pengetahuan tentang prasyarat pembelajaran dan kesulitan-kesulitan peserta didik. Pengetahuan penilaian mengenai aspek-aspek penilaian pembelajaran dan pengetahuan tentang metode penilaian yaitu cara yang digunakan untuk menilai aspek-aspek pembelajaran. Pengetahuan strategy pembelajaran adalah pengetahuan tentang strategi pembelajaran sains dan topik-topik sains.

Sementara itu Jang et.all (2009) menjelaskan bahwa kemampuan PCK dibagi dalam empat kategori yaitu: subject mater knowledge (SMK), instructions representation and strategies (IRS), instructional objectives and context (IOC), dan knowledges of student understanding (KSU). SMK merupakan persepsi siswa terhadap pemahaman guru dengan materi yang tengah diajarkannya. IRS adalah persepsi siswa terhadap kemampuan guru dalam menyampaikan materi pelajaran baik melalui penjelasan-penjelasan, menggunakan analogi-analogi, contoh-contoh melalui pemilihan strategi pembelajaran yang tepat, ketika berdiskusi dan saat menggunakan alat-alat teknologi. IOC adalah pengetahuan guru tentang maksud serta tujuan pembelajaran, suasana interaktif pembelajaran sebagai bagian dari kurikullum, sikap guru, pengelolaan kelas, pengetahuan tentang konteks nilai-nilai dari materi pembelajaran. KSU adalah persepsi siswa tentang bagaimana guru mampu mengevaluasi pemahaman siswa yang sebenarnya sebelum, selama pengajaran dan pada akhir pelajaran.

Program studi pendidikan Fisika FKIP Universitas Jambi sebagai salah satu institusi pendidikan yang mempersiapkan seorang mahasiswa untuk menjadi guru yang profesional telah melakukan berbagai usaha guna mencapai tujuan tersebut. Pembelajaran yang berisi konten-konten fisika, pembelajaran tentang pedagogik, pembelajaran tentang strategi pembelajaran dan teori-teori perkembangan siswa sudah diajarkan melalui berbagai matakuliah. Tidak hanya diajarkan secara teoritis, mahasiswa juga diberi kesempatan untuk menampilkan kemampuan PCKnya pada matakuliah pembelajaran mikro pada semester V dan pada matakuliah Praktik Lapangan Persekolahan (PLP) pada semester VII. Sebagai mahasiswa semester VII yang sedang melaksanakan kegiatan PLP yang sudah menyelesaikan hampir seluruh matakuliahnya, maka peneliti tertarik untuk mengetahui kemampuan 
PCK nya sebagai representatif lulusan program studi Pendidikan Fisika FKIP Universitas Jambi. Penelitian ini bertujuan untuk mendeskripsikan kemampuan pedagogical content knowledge mahasiswa Pendidikan Fisika Universitas Jambi yang mengikuti Praktik Lapangan Persekolahan (PLP).

\section{Metode Penelitian}

Penelitian ini adalah penelitian survei guna mengungkap dan menganalisa tingkatan kemampuan pedagogical content knowledge mahasiswa program studi Pendidikan Fisika Universitas Jambi yang tengah menjalani program praktik lapangan persekolahan pada berbagai sekolah di kota Jambi. Populasi pada penelitian ini adalah seluruh mahasiswa peserta praktik lapangan pesekolahan tahun 2019 di Program Studi Pendidikan Fisika FKIP Universitas Jambi yang berjumlah 85 orang mahasiswa dengan sampling sebanyak $20 \%$ populasi yaitu sebanyak 17 orang mahasiswa. Prosedur penelitian yang dilakukan sebagai berikut:

Langkah 1. Penentuan sampel

Peneliti menentukan sampel penelitian yakni mahasiswa program studi pendidikan fisika peserta matakuliah praktik lapangan persekolahan.

Langkah 2. Adopsi instrumen angket persepsi siswa terhadap kemampuan pedagogical content knowledge guru. Peneliti mengadopsi instrumen Angket persepsi siswa terhadap kemampuan pedagogical content knowleddge guru yang dibuat oleh Jang at all (2009) untuk diberikan kepada siswa yang diajarkan oleh mahasiswa PLP.

Langkah 3. Pemberian angket kepada mahasiswa

Angket persepsi siswa terhadap kemampuan pedagogical content knowledge guru diberikan kepada siswa yang diajar oleh sampel penelitian (mahasiswa peserta PLP program studi pendidikan fisika tahun 2019 yang berjumlah 17 mahasiswa).

Langkah 4. menginput data dan menganalisa data angket

Peneliti melakukan input persepsi siswa terhadap kemampuan pedagogical content knowledge guru, serta menganalisa data angket dengan statistik deskriptif.

Langkah 5. Interprestasi data

Interprestasi data dilakukan bertujuan untuk memetakan kemampuan pedagogical content Knowledge mahasiswa peserta matakuliah praktik lapangan persekolahan.

Instrumen dalam penelitian menggunakan angket yaitu angket persepsi siswa tentang kemampuan Pedagogical Content Knowledge (PCK) guru yang dibuat oleh de Jang at all (2009) dengan empat indikator yaitu: subject mater knowledge (SMK), instructions representation and strategies (IRS), instructionall objectives and context (IOC), dan knowledge of students understanding (KSU) dengan masing-masing indikator terdiri dari 7 pernyataan. Pengisian angket dilakukan dengan cara memberi tanda checklist $(\sqrt{ })$ pada kolom pilihan kuesioner, dimana pada setiap item menggunakan lima jawaban yaitu dengan menggunakan skala likert, yang diubah dalam bentuk angka dengan rentang angka 1 sampai 5 sebagai berikut, angka 1 (tidak pernah), angka 2 (jarang), angka 3 (kadang-kadang), dan angka 4 (sering) dan 5 (selalu).

Analisa data instrumen angket mempergunakan statistik deskriptif. Sugiyono (2016) menjelaskan statistik deskriptif dapat digunakan untuk menganalisis data dengan cara memberikan deskripsi atau memberi gambaran terhadap data yang ada sebagaimana adanya dan bukan dimaksudkan untuk membuat kesimpulan umum atau generalisasi. Dalam analisis deskriptif digunakan tabel frekuensi untuk membantu mengkategorikan hasil analisis data yang didapatkan. Dalam tabel frekuensi terdapat rentang skor untuk setiap skala angket untuk menentukan skor yang didapat dalam analisis angket (Widoyoko, 2016). Setiap indikator angket memiliki jumlah item sebanyak 7 buah item, dengan menggunakan skala Likert 1 sampai 5, maka skor maksimum yang di peroleh adalah 35 dan skor minimum adalah 7. Kemampuan Pedagogical Content Knowledge mahasiswa dapat dikategorikan dengan mengacu tabel 1. 
Tabel 1. Kategori pedagogical content knowledge

\begin{tabular}{cc}
\hline Rentang Skor & Kategori \\
\hline $7.0-12.6$ & Sangat Tidak Baik \\
$12.6-18.2$ & Tidak Baik \\
$18.2-23.8$ & Sedang \\
$23.8-29.4$ & Baik \\
$29.4-35.0$ & Sangat Baik \\
\hline
\end{tabular}

\section{Hasil dan Pembahasan}

Tingkat kemampuan PCK seorang guru dapat dilihat skor persepsi siswa dari empat kategori yaitu: subject mater knowledge (SMK), instructions representation and strategies (IRS), instructionall objective and context (IOC), dan knowledge of students understanding (KSU). SMK merupakan persepsi siswa sehubungan dengan pemahaman guru terhadap materi pelajaran. IRS adalah persepsi siswa sehubungan dengan pemilihan strategi penyampaian materi, pemilihan metode, pemilihan media teknologi, memberikan contoh dan analogi-analogi serta memberikan penjelasan-penjelasan yang memudahkan siswa dalam memahami materi pelajaran. IOC merupakan persepsi siswa tentang pengetahuan guru terhadap tujuan pendidikan, kurikulum, pengelolaan kelas, pengetahuan kontekstual serta nilai-nilai dari proses belajar mengajar. KSU merupakan persepsi siswa tentang pemahaman guru dalam mengevaluasi pembelajaran sebelum, selama dan sesudah proses belajar mengajar.

Instrumen pengumpulan data adalah kuisioner dimana tiap-tiap indikator PCK terdapat 7 item peryataan, dengan demikian terdapat 28 item pernyataan untuk keseluruhan indikator. Setelah kuisioner diisi untuk masing-masing mahasiswa diolah secara deskriptif untuk menentukan rata-rata, nilai maksimum, nilai minimum dan simpangan bakunya. Data hasil pengolahan data untuk setiap indikator ditunjukkan pada table 2 sebagai berikut.

Tabel 2. Subjek mater knowlegde

\begin{tabular}{lccccl}
\hline Mhs PLP & Rata-Rata & Maksimal & Minimal & Standar Deviasi & \multicolumn{1}{c}{ Kategori } \\
\hline 1 & 28,07 & 35 & 20 & 5,70 & Baik \\
2 & 29,92 & 35 & 21 & 4,59 & Sangat Baik \\
3 & 28,36 & 35 & 17 & 4,95 & Baik \\
4 & 28,24 & 34 & 14 & 5,88 & Baik \\
5 & 29,32 & 34 & 22 & 3,73 & Baik \\
6 & 28,64 & 35 & 22 & 3,38 & Baik \\
7 & 24,38 & 33 & 19 & 4,84 & Baik \\
8 & 26,14 & 34 & 19 & 4,14 & Baik \\
9 & 28,87 & 35 & 18 & 4,68 & Baik \\
10 & 30,17 & 33 & 24 & 2,23 & Sangat Baik \\
11 & 17,09 & 24 & 11 & 3,25 & Tidak Baik \\
12 & 26,35 & 30 & 22 & 1,97 & Baik \\
13 & 26,17 & 29 & 23 & 2,09 & Baik \\
14 & 28,23 & 35 & 22 & 2,90 & Baik \\
15 & 29,42 & 35 & 19 & 3,45 & Sangat Baik \\
16 & 26,43 & 35 & 7 & 6,37 & Baik \\
17 & 30,50 & 35 & 24 & 3,37 & Sangat Baik \\
Total & $\mathbf{2 7 , 4 9}$ & $\mathbf{3 5}$ & $\mathbf{7}$ & $\mathbf{4 , 9 3}$ & Baik \\
\hline
\end{tabular}

Dari Tabel 2 menunjukkan bahwa kemampuan mahasiswa tentang subject matter knowledge rata-rata adalah 27,49 dengan simpangan baku sebesar 4,93 dan ini termasuk pada kategori baik. Dari 17 orang sampel, diketahui 4 orang mahasiswa memiliki kategori sangat baik, 12 orang mahasiswa kategori baik dan satu orang mahasiswa dengan kategori tidak baik. Ini memberi gambaran bahwa 
penguasaan konsep fisika mahasiswa secara rata-rata telah baik dan cukup memadai untuk menjadi guru fisika di sekolah menengah. Hal ini disebabkan bahwa mahasiswa yang sedang melakukan kegiatan PLP adalah mahasiswa semester VII yang pada umumnya telah mengambil dan lulus untuk semua matakuliah-matakuliah konten dan memahami konsep-konsep fisika dengan baik.

Baiknya persepsi siswa terhadap kemampuan content knowledge mahasiswa sesuai dengan pernyataan Leung and Park (2002) bahwa penguasaan content knowledge oleh guru akan menentukan cara guru membelajarkan siswa pada materi itu, menentukan cara guru mengembangkan bahan ajar dan evaluasi, serta menentukan materi mana yang akan dipelajari siswa. Oleh sebab itu mahasiswa yang memiliki content knowledge yang baik akan mampu membelajarkan siswa dengan baik dan memudahkan siswa sehingga dipersepsi siswa dengan baik.

Tabel 3.Instruction representation and strategies (IRS)

\begin{tabular}{lccccl}
\hline Mhs PLP & Rata-Rata & Maksimal & Minimal & Standar deviasi & Kategori \\
1 & 24,96 & 31 & 16 & 4,27 & Baik \\
2 & 28,31 & 35 & 17 & 4,92 & Baik \\
3 & 26,56 & 35 & 16 & 5,02 & Baik \\
4 & 25,71 & 32 & 11 & 4,33 & Baik \\
5 & 28,00 & 33 & 16 & 4,07 & Baik \\
6 & 25,68 & 32 & 15 & 3,79 & Baik \\
7 & 24,38 & 33 & 19 & 4,84 & Baik \\
8 & 23,95 & 31 & 19 & 2,65 & Baik \\
9 & 28,79 & 35 & 21 & 4,13 & Baik \\
10 & 27,94 & 34 & 23 & 3,42 & Baik \\
11 & 17,36 & 25 & 12 & 3,36 & Tidak Baik \\
12 & 28,76 & 33 & 21 & 2,19 & Baik \\
13 & 26,69 & 30 & 22 & 1,94 & Baik \\
14 & 25,08 & 35 & 20 & 3,07 & Baik \\
15 & 26,61 & 35 & 15 & 4,68 & Baik \\
16 & 23,77 & 35 & 7 & 5,38 & Sedang \\
17 & 30,42 & 35 & 19 & 5,22 & Sangat Baik \\
Total & $\mathbf{2 6 , 0 6}$ & $\mathbf{3 5}$ & $\mathbf{7}$ & $\mathbf{4 , 8 5}$ & Baik \\
\hline
\end{tabular}

Dari Tabel 3 menunjukkan bahwa dari 17 orang mahasiswa, termasuk kategori sangat baik, tidak baik dan sedang masing masing 1 orang, sementara sisanya sebanyak 14 orang lainnya termasuk kategori baik untuk komponen Instruction representation and strategies (IRS). Rerata skor pada semua aspek IRS adalah 26,06 dengan Simpangan Baku 4,85 dalam kategori baik. Ini berarti mahasiswa sudah mampu menentukan strategi pembelajaran dengan tepat serta melaksanakannya dalam proses pembelajaran di sekolah. Kemampuan ini dapat diperoleh mahasiswa melalui matakuliah strategi pembelajaran dan latihan mengajar pada matakuliah pembelajaran mikro. Hasil penelitian Indrawati dalam Indrawati (2016) menyatakan kemampuan mahasiswa untuk memilih dan melaksanakan strategi pembelajaran bisa perbaiki lewat latihan berulangulang.

Selama kegiatan praktik mengajar mahasiswa telah merancang pembelajaran yang membuat siswa lebih aktif dengan menggunakan model pembelajaran problem base learning dengan dibantu media simulasi dan animasi. Keaktifan siswa dalam pembelajaran telah dipersepsikan oleh siswa sebagai kemampuan yang baik yang dimilki oleh guru dalam pembelajaran. Penguasaan pedagogical knowledge terutama pada indikator penguasaan strategi khususnya strategi pembelajaran yang meningkatkan keaktifan siswa dalam belajar secara mandiri dengan mempertimbangkan karakteristik siswa adalah sangat penting dimiliki seorang guru. (Arnyana, 2007).

Tabel 4. Instructional objective and context (IOC) 


\begin{tabular}{lccccl}
\hline Mhs PLP & Rata-Rata & Maksimal & Minimal & Standar deviasi & Kategori \\
1 & 26,71 & 34 & 20 & 3,88 & Baik \\
2 & 29,35 & 35 & 14 & 5,16 & Baik \\
3 & 27,92 & 35 & 18 & 4,84 & Baik \\
4 & 28,47 & 35 & 13 & 4,94 & Baik \\
5 & 27,37 & 32 & 23 & 3,09 & Baik \\
6 & 25,52 & 32 & 15 & 4,98 & Baik \\
7 & 23,75 & 31 & 20 & 2,86 & Sedang \\
8 & 24,95 & 31 & 16 & 3,37 & Baik \\
9 & 27,33 & 34 & 19 & 4,42 & Baik \\
10 & 30,06 & 35 & 25 & 3,24 & Sangat Baik \\
11 & 16,27 & 23 & 8 & 4,11 & Tidak Baik \\
12 & 28,38 & 35 & 21 & 3,57 & Baik \\
13 & 26,83 & 32 & 22 & 2,79 & Baik \\
14 & 25,31 & 35 & 17 & 3,87 & Baik \\
15 & 28,00 & 35 & 18 & 4,18 & Baik \\
16 & 24,40 & 35 & 7 & 6,31 & Baik \\
17 & 28,69 & 35 & 19 & 4,36 & Baik \\
Total & $\mathbf{2 6 , 4 9}$ & $\mathbf{3 5}$ & $\mathbf{7}$ & $\mathbf{5 , 0 7}$ & Baik \\
\hline
\end{tabular}

Dari Tabel 4 menunjukkan terdapat masing-masing 1 orang memiliki kemampuan sangat baik, sedang dan buruk, serta selebihnya sebanyak 14 orang mahasiswa memiliki kemampuan baik untuk indikator Instructional objective and context (IOC). Ini dapat ditunjukkan dari rerata skor 26,49 dengan simpangan baku 5,07. Data ini memberi kesimpulan bahwa mahasiswa sudah mampu merumuskan tujuan pembelajaran serta menghubungkan dengan kontek baik materi maupun audien dengan baik, karena merumuskan tujuan pembelajaran memerlukan pemahaman karakteristik siswa dengan baik.

Tabel 5. Knowledge of student understanding (KSU)

\begin{tabular}{lrcccl}
\hline Mhs PLP & Rata-Rata & Maksimal & Minimal & Standar deviasi & Kategori \\
1 & 25,42 & 35 & 16 & 5,06 & Baik \\
2 & 29,00 & 35 & 19 & 4,26 & Baik \\
3 & 27,36 & 35 & 17 & 5,33 & Baik \\
4 & 27,38 & 35 & 10 & 5,71 & Baik \\
5 & 29,21 & 34 & 19 & 3,70 & Baik \\
6 & 27,44 & 33 & 20 & 3,73 & Baik \\
7 & 22,87 & 29 & 17 & 4,06 & Sedang \\
8 & 25,95 & 31 & 17 & 3,41 & Baik \\
9 & 27,83 & 35 & 20 & 4,10 & Baik \\
10 & 29,72 & 33 & 24 & 2,80 & Sangat Baik \\
11 & 16,77 & 21 & 9 & 3,32 & Tidak baik \\
12 & 24,76 & 32 & 17 & 3,51 & Baik \\
13 & 26,58 & 31 & 21 & 2,14 & Baik \\
14 & 27,14 & 35 & 19 & 3,22 & Baik \\
15 & 27,12 & 35 & 14 & 4,68 & Baik \\
16 & 25,14 & 35 & 7 & 6,13 & Baik \\
17 & 28,31 & 35 & 18 & 4,27 & Baik \\
Total & $\mathbf{2 6 , 3 5}$ & $\mathbf{3 5}$ & $\mathbf{7}$ & $\mathbf{4 , 9 3}$ & Baik \\
\hline
\end{tabular}

Pada Tabel 5 dapat dilihat skor rata-rata KSU adalah 26,36 pada kategori baik dan simpangan baku sebesar 4,93. Sebanyak 14 orang mahasiswa memperoleh kategori baik, dan masing masing satu pada kategori tidak baik, sedang dan sangat baik. Kemampuan KSU yang baik membuktikan pengetahuan mahasiswa tentang karakteristik siswa, terutama perkembangan intelektual siswa sudah mencukupi. Sebelum mengajar mahasiswa sudah menyadari kemampuan awal siswa serta sudah 
mampu mengantisipasinya dengan baik. Mukhtar (2001) menjelaskan guru sebaiknya dapat mengenal tiap siswa di dalam kelasnya secara individual dengan semua keunikannya dengan cermat, sehingga mampu memahami kelebihan serta kekurangan setiap siswanya.

\section{Simpulan}

Kemampuan Pedagogical Content Knowledge (PCK) mahasiswa Pendidikan Fisika yang mengikuti Pratik Lapangan Persekolahan PLP berada pada kategori baik. Aspek Pedagogical Content Knowledge (PCK) terdiri dari subject mater knowledge, instructionall objective and context, instructions representation and strategies, dan knowledges of student understanding.

\section{Referensi}

Abell, S. K. (2008). Twenty Years later remain useful idea? International Journal of Science Education, Vol. 30, No. 10, 13 August 2008, pp. 1405-1416. 3

Abbitt, J.T. 2011. Measuring Technological Pedagogical Content Knowledge in Preservice Teacher Education: A Review of Current Methods and Instruments. Journal of Research on Technology in Education. 43(4): 281-300.

Anwar Yenni, dkk. 2014. Kemampaan Pedagogical Content Knowledge Guru Biologi Yang Berpengalaman dan yang Belum Berpengalaman. Jurnal Fakultas Pendidikan Matematika dan Ilmu Pengetahuan Alam Universitas Pendidikan Indonesia. Volume 19 No 1 ISSN 1412-0917

Arnyana, I.B.P. 2007. Pengembangan Profesionalisme Guru Biologi di Era Global. Jurnal Pendidikan dan Pengajaran UNDIKSHA. Edisi Khusus XXXX:472-490.

Hariyanti Eni HW. 2016. Profil Pedagogical Content Knowledge Mahasiswa Calon Guru Biologi. Universitas PGRI Semarang. Jurnal Bioma Vol.5 No.1

Indrawati dan Sutarto (2016) Studi Pedagogical Content Knowledge (Pengetahuan Konten Pedagogik) Mahasiswa Calon Guru Fisika disampaikan dalam Seminar Nasional Pendidikan 2016 "Peran Pendidikan, Sains, Dan Teknologi Dalam Membangun Intelektual Bangsa Dan Menjaga Budaya Nasional Di Era Mea"21 Mei Issn : 2527 -5917, Vol.1

Kastutik Anita Windy dan Hariyatmi. 2017. Profil Kemampuan Pedagogical Content Knowledge (PCK) Guru IPA Kelas VIII SMP Negeri di Kabupaten Sukoharjo. Universitas Muhammadiyah Surakarta. Seminar Nasional Pendidikan Biologi dan Saintek II. ISSN 2527$533 \mathrm{X}$

Laoli Yarni dan Bunawan Wawan. 2017. Implementasi Pedagogical Content Knowledge (PCK) Berbasis Inkuiri Terbimbing Terhadap Hasil Belajar Siswa. Universitas Negeri Medan. Jurnal Infapi Vol. 5 No. 4 e-ISSN 2549-8258

Leung, F., and K. Park. 2002. Competent Students, Competent Teachers? International Journals of Educational Research. 37(2): 113129

Margiyono Iis dan Mampouw Helti Lygia. 2011. Deskripsi Pedagogical Content Knowledge Guru Pada Bahasan Tentang Bilangan Rasional. Internationa Seminar and the Fourth National Cinference on Mathematics Education. Departement of Mathematics Education. Yogyakarta State University : Yogyakarta ISSN 978-979-16353-7-0

Mukhtar, dkk, (2001). Mengukir Prestasi Panduan Menjadi Guru Profesional. Jakarta: Misaka Galiza.

Purwaningsih, Endang (2015) Potret Representasi Pedagogical Content Knowledge (PCK) Guru dalam Mengajarkan Materi Getaran dan Gelombang pada Siswa Smp. Indonesian Journal of Applied Physics (2015) Vol.5 No.1 hal.9 
Resbiantoro Gaguk. 2013. Analisis Pedagogical Content Knowledge (PCK) Terhadap Buku Guru Sd Kurikulum 2013. STKIP PGRI Tulungagung. Jurnal Scholaria Vol. 6 No. 3

Syh-Jong Jang*, Shih-Ying Guana, Hsing-Fen Hsieha (2009). World Conference on Educational Sciences 2009 Developing an instrument for assessing college students' perceptions of teachers' pedagogical content knowledge aGraduate School of Education, Chung Yuan Christian University, No. 200, Chungpei Rd., Chungli City, Taoyuan County 320, Taiwan

Sugiyono. 2016. Metode Penelitian Kuantitatif, Kualitatif, Dan R \& D. Bandung: Alfabeta

Sukadi Eti, dkk. 2015. Implementasi Pedagogical Content Knowledge pada Materi Listrik Dinamis untuk Meningkatkan Kompetensi Calon Guru Fisika. Universitas Senelas Maret. Jurnal Inkuiri. ISSN 2252-7893, Vol 4, No. 1

Shulman. 1986. Those Who Understand: Knowledge Growth in Teaching. Educational Research. 15(2): $4-14$

Shulman, L.S. (1987). Knowledge and teaching: Foundations of the new reform. Harvard Educational Review, 57, 1-22.

Widoyoko, E P. 2016. Teknik penyusunan Instrumen Penelitian. Yogyakarta: Pustaka Pelajar 